\title{
A new Early Jurassic gastropod from Ellesmere Island, Canadian Arctic - an ancient example of holoplanktonic gastropods
}

\author{
Alexander Nützel, Simon Schneider, Peter Hülse, Simon R.A. Kelly, Laura Tilley \& \\ † REINHART VEIT
}

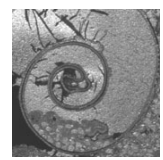

\begin{abstract}
A new, most probably holoplanktonic gastropod genus and species, Freboldia fluitans Nützel \& Schneider, is reported from the Early Jurassic (Pliensbachian) of Ellesmere Island, Canadian Arctic. Its shell is very thin, small, with a maximum diameter of $8 \mathrm{~mm}$, inflated, planispiral and almost bilaterally symmetric, with deep umbilici. Hundreds of specimens of Freboldia occur in the matrix of transported siltstone concretions. In summary, these characteristics suggest a holoplanktonic lifestyle for Freboldia. Similar shells are present in the modern holoplanktonic gastropod family Limacinidae and in Cretaceous Bellerophinidae, and the new species is assigned to the latter family. The oldest records of holoplanktonic or pelagic gastropods are represented now by seven Early Jurassic genera: Coelodiscus, Tatediscus, Costasphaera, Pterotrachea, Simoniceras, Globorilusopsis and the new genus Freboldia. These are attributed to five different clades, which made their appearance at approximately the same time. We thus speculate that Early Jurassic anoxia triggered the rapid evolution of the holoplanktonic lifestyle in gastropods. Key words: Jurassic, Canadian Arctic, pelagic holoplanktonic gastropoda, Pliensbachian, anoxia.
\end{abstract}

NÜTZEL, A., Schneider, S., HÜlSe, P., Kelly, S.R.A., TILlEy, L. \& † VeIt, R. 2016. A new Early Jurassic gastropod from Ellesmere Island, Canadian Arctic - an ancient example of holoplanktonic gastropods. Bulletin of Geosciences 91(2), 229-242 (8 figures, 1 table). Czech Geological Survey, Prague. ISSN 1214-1119. Manuscript received December 8, 2015; accepted in revised form February 25, 2016; published online May 19, 2016; issued June 30, 2016.

Alexander Nützel (corresponding author), SNSB - Bayerische Staatssammlung für Paläontologie und Geologie, Department of Earth and Environmental Sciences, Palaeontology \& Geobiology, GeoBio-Center LMU, Richard-Wagner-Str. 10, 80333 München, Germany; a.nuetzel@lrz.uni-muenchen.de•Simon Schneider, Peter Hülse and Simon R.A. Kelly, CASP, 181A Huntingdon Road, Cambridge CB3 ODH, United Kingdom $\bullet$ Laura Tilley, School of Earth and Environment, University of Leeds, Maths/Earth and Environment Building, Leeds LS2 9JT, United Kingdom • Reinhart Veit, Posthaltergasse 3, 84149 Velden an der Vils, Germany (recently deceased)

Living holoplanktonic or pelagic snails are of moderate diversity ( 140 species) but may be highly abundant and, owing to their lifestyle, widely distributed (e.g., Lalli \& Gillmer 1989). In places, particularly around ocean islands, above the aragonite compensation depth, dead shells of holoplanktonic gastropods may form a major component of the sediment, which is termed pteropod ooze (see Chen 1964, and references therein). A pelagic or planktonic lifestyle has evolved independently in Caenogastropoda and Heterobranchia and is probably polyphyletic even within these groups. Commonly these gastropods are considered to be planktonic although most of them are able to swim actively (Lalli \& Gilmer 1989).

As summarized by Janssen \& Peijnenburg (2013), the earliest certain members of the pteropods (planktonic Heterobranchia) are known from the late Palaeocene. Maubeuge (1998) discussed two Early Jurassic genera,
Globorilusopsis and Simoniceras, including several species as being possibly related to the pteropods. However, while a holoplanktonic mode of life is possible in these Early Jurassic gastropods (see discussion below), an attribution to pteropods needs further testing.

Similarly, most modern heteropod families (planktonic Caenogastropoda) originate in the Cenozoic (see Janssen \& Peijnenburg 2013 and Teichert \& Nützel 2015 and references therein). However, a planktonic mode of life has been proposed for several Mesozoic gastropod genera, which were attributed to the heteropods. Brunonia and Bellerophina were reported from the Cretaceous (Destombes 1987, Dieni 1990). Additionally, several Early Jurassic gastropod genera, i.e. Coelodiscus, Tatedicus, Pterotrachea and Costasphaera, have been assigned to the heteropods (Bandel \& Hemleben 1987, Nützel \& Gründel 2015, Nützel \& Teichert 2015). 


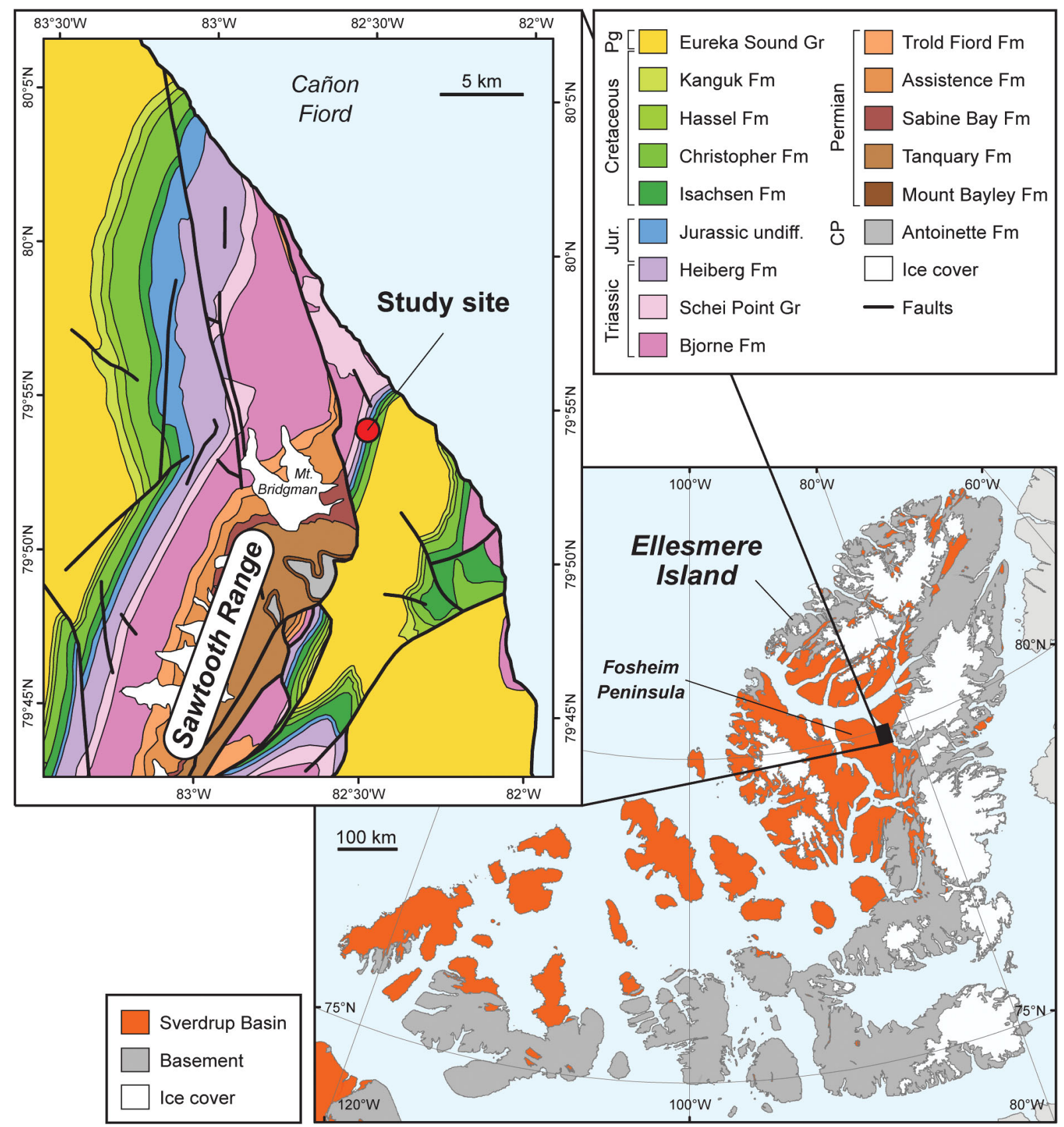

Figure 1. Geological overview of the Queen Elizabeth Islands, Arctic Canada (modified from Harrison et al. 2011) and the study area (inset map, modified from Thorsteinsson 1972). The study site is indicated by a red dot. Abbreviations: $\mathrm{Gr}=$ group; Fm = formation; undiff. = undifferentiated; $\mathrm{Pg}=$ Paleogene; Jur. $=$ Jurassic $; \mathrm{CP}=$ Carboniferous to Permian.

Herein, we describe a new genus and species of putative Heteropoda, Freboldia fluitans Nützel \& Schneider, from the Pliensbachian (Early Jurassic) of Ellesmere Island, Arctic Canada, which is assigned to the Bellerophinidae. The sudden appearance and considerable diversity of putative holoplanktonic gastropods in the Early Jurassic is noted, and potential underlying causes are discussed.

\section{Geological setting}

The fossils were collected along a river section northeast of Mount Bridgman (N 79 54.209, W 82 $\left.{ }^{\circ} 29.944\right)$, on the eastern side of the Sawtooth Range on Fosheim Peninsula, Ellesmere Island, Nunavut Province, Arctic Canada (Fig. 1). During the Early Jurassic, this area was part of the Sverdrup Basin, which is located in the Queen Elizabeth 


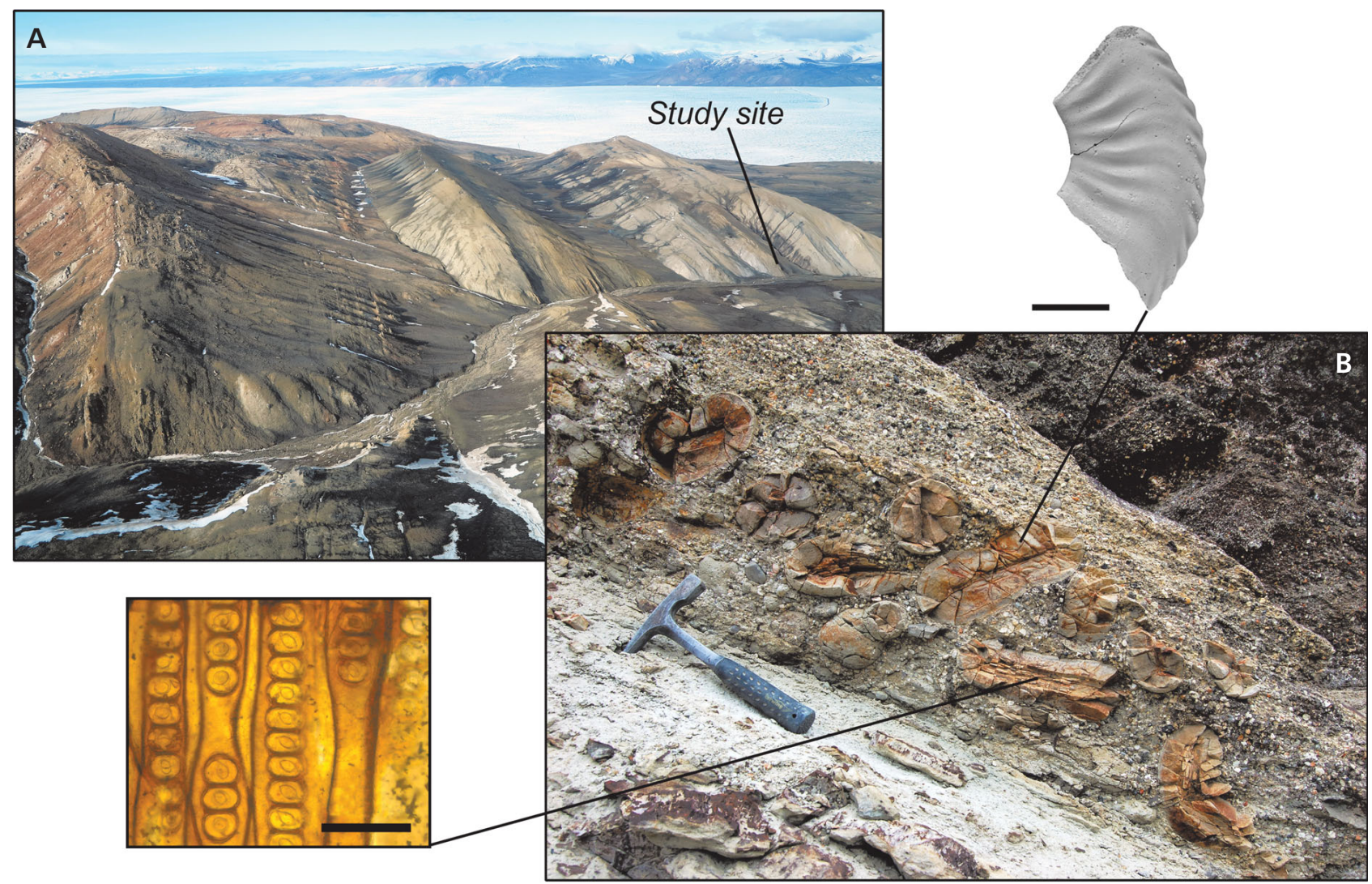

Figure 2. Outcrop. • A - river section east of Mount Bridgman, eastern slopes of Sawtooth Range, Fosheim Peninsula, Ellesmere Island. View from south, from helicopter. The position of the study site is indicated. Total width of photograph approximately $1.5 \mathrm{~km}$. $\bullet$ B - siltstone concretions with pieces of fossilised wood as cores (early Late Pliensbachian in age), reworked into a polymictic conglomerate (Late Pliensbachian/Early Toarcian? in age); top part of Remus Member, Heiberg Formation. Length of hammer is approximately $40 \mathrm{~cm}$. Upper right: Amaltheus stokesi (J. Sowerby), index fossil of the Stokesi subzone, CMN NUIF 419. Lower left: Radial longitudinal thin section of Xenoxylon sp. from the core of a concretion, CMN NUPB 464.

Islands and interisland channels (Nunavut and the Northwest Territories) and covers an area of approximately $300,000 \mathrm{~km}^{2}$ (e.g. Schröder-Adams et al. 2014; Fig. 1). The study site was situated close to the eastern basin margin. Based on the palaeolatitude calculator of van Hinsbergen $e t$ al. (2015), a Pliensbachian palaeolatitude between $65^{\circ}$ and $70^{\circ} \mathrm{N}$ can be assumed for this site.

The Sverdrup Basin is filled with up to $13 \mathrm{~km}$ of Carboniferous to Eocene sedimentary strata, which were deposited during eight major phases of development as proposed by Embry \& Beauchamp (2008). These phases are characterised by distinct tectonic and depositional regimes and bounded by unconformities. The latest Triassic to earliest Cretaceous phase 5, characterised by widespread deposition of shallow offshore shelf deposits (Embry \& Beauchamp 2008), is relevant to the present study. During the Rhaetian to Early Pliensbachian, the study area was part of an extensive delta plain, testified by the occurrence of massive, trough-cross-bedded sandstone beds with abundant plant material in the study section (Fosheim Member, Heiberg Formation; Embry 1983, Embry \& Suneby 1995). Transgression in the Pliensbachian is repre- sented by shallow-marine, partly sideritic sandstones, as demonstrated by intense bioturbation and the occurrence of shallow-marine bivalve and brachiopod assemblages (Remus Member, Heiberg Formation; Embry 1983). Outcrop is mediocre in this part of the section, and presumable mud- to siltstone intervals are covered by scree.

The most prominent interval at outcrop is a more than five metres thick succession of polymictic conglomerates, composed of several individual beds, which are partly impregnated with siderite and form a distinct ridge in the section (Fig. 2A). The present interpretation is that the conglomerates were deposited during transgression in a nearshore environment. At the base of the lowermost horizon, 10 to $40 \mathrm{~cm}$ long oval mudstone to siltstone concretions, formed around pieces of fossilised wood, are present in the conglomerate (Fig. 2B). Several of these concretions preserve a single, up to $5 \mathrm{~cm}$ thick fossiliferous horizon, which yielded the fossil assemblage discussed herein. The different matrix of the concretions and the conglomerate, the random orientation of the concretions and the discontinuity of the fossil layer clearly indicate that the concretions are reworked into the conglomerate. 


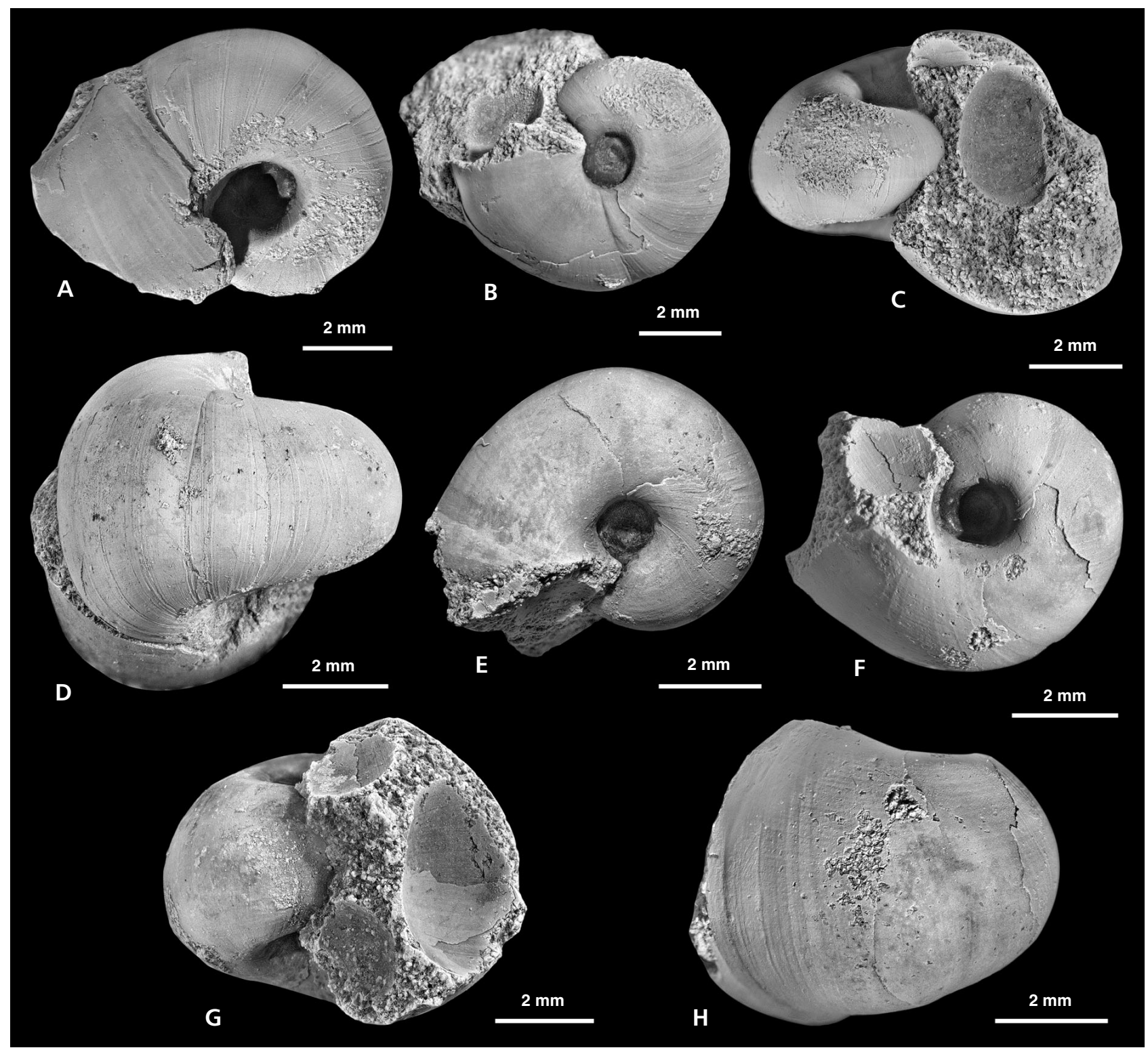

Figure 3. Freboldia fluitans gen. nov. sp. nov., coated with ammonium chloride for photographs. • A-D - paratype 1, CMN NUIF 1234 . E-H paratype 2, CMN NUIF 1235. All scale bars $2 \mathrm{~mm}$.

The reworked concretions and the enclosed fossil assemblage are accurately dated as earliest Late Pliensbachian by the occurrence of the ammonite Amaltheus stokesi (J. Sowerby, 1818), index species of the Stokesi Subzone of the Margaritatus Zone (e.g. Dommergues et al. 1997, Simms et al. 2004). Precise dating for the conglomerate layer itself is lacking. Assuming that it forms the top of the Remus Member, it should be latest Pliensbachian in age, but an (early) Toarcian age cannot be ruled out. With a significant interval of non-exposure, the conglomerates are overlain by intensely bioturbated mudstones, presumably of Toarcian age (Cape Canning Member, Jameson Bay Formation; Embry 1984, Embry \& Johannessen 1992).
Two taxa of fossil conifer wood (Cupressinoxylon and Xenoxylon) have been identified from the fragments forming the cores of the concretions. Besides the supposedly holoplanktonic gastropods described herein, the fossil assemblage preserved in the matrix of the concretions yielded ammonites (Amaltheus stokesi, Gemellaroceras?), epi- and endobenthic bivalves (Palaeonucula, Parvamussium?, Meleagrinella, Limidae indet., Liotrigonia?, Isotancredia?, Goniomya), benthic gastropods (Pleurotomarioidea, Ataphridae), scaphopods (Laevidentalium) and a decapod fragment. The holoplanktonic gastropods occur en masse, comprising more than $90 \%$ of the specimens collected. The fossil assemblage, its palaeoecology and its peculiar taphonomy will be described in a separate study. 

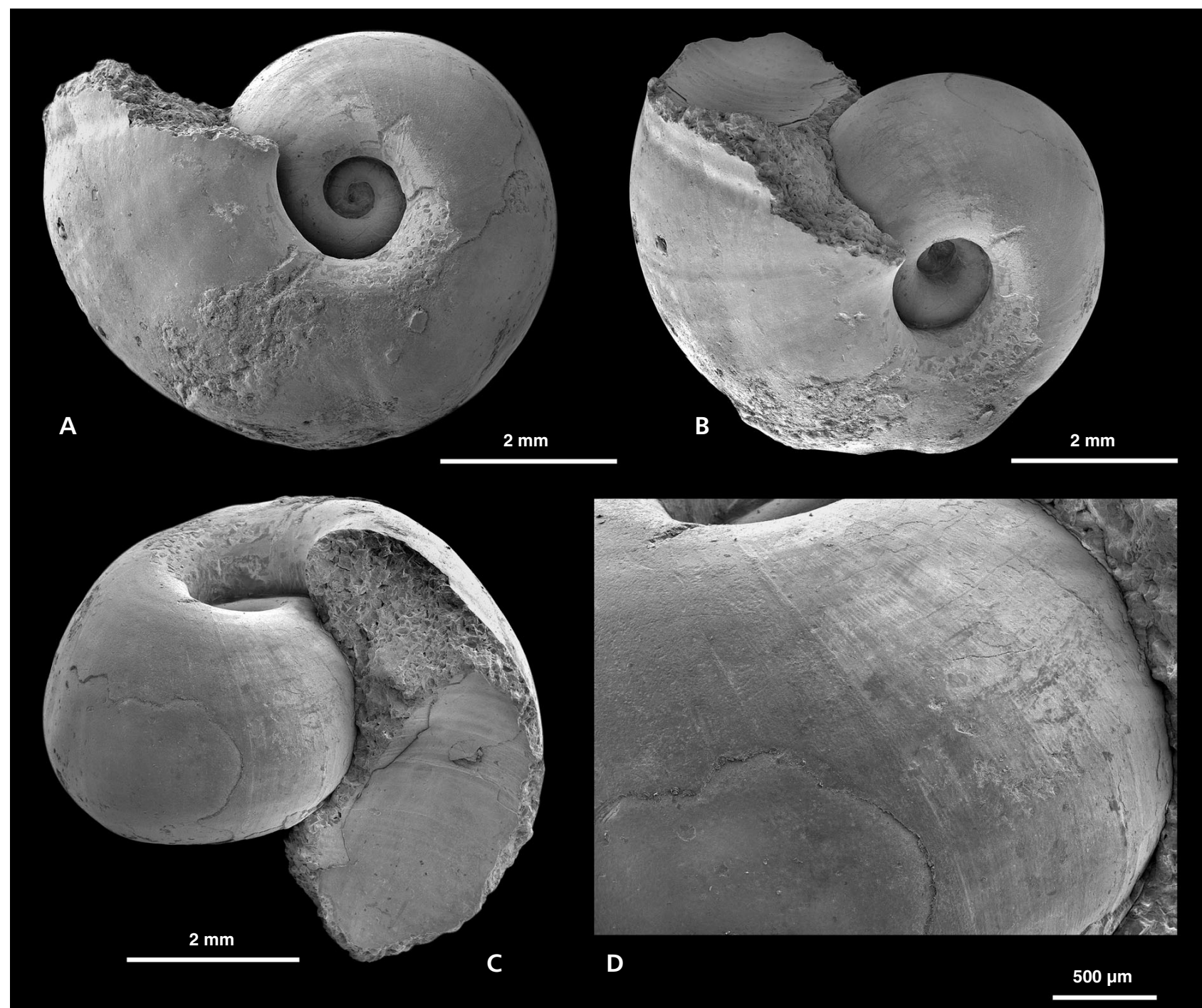

Figure 4. Freboldia fluitans gen. nov. sp. nov., holotype, SEM micrographs, CMN NUIF 422.

All fossil specimens from Ellesmere Island are stored in the collections of the Canadian Museum of Nature, Ottawa, Canada, (CMN) under collection numbers CMN NUIF 419 (Amaltheus stokesi), 422 (holotype of Freboldia fluitans), and 1234-1243 (paratypes and additional material of Freboldia fluitans), as well as CMN NUPB 464 (wood thin section).

\section{Systematic palaeontology}

Family Bellerophinidae Destombes, 1984

This family is based on the genus Bellerophina d'Orbigny, 1843 with its Early Cretaceous type species Bellerophina minuta (J. Sowerby, 1812). Except for Brunonia, it is the only putative holoplanktonic gastropod genus known from the Cretaceous. It is more or less bilaterally symmetrical with a diameter of up to $6 \mathrm{~mm}$. Measurements of the shell thickness have not been provided, but according to published photographs (Destombes 1984, Tracey 2010), the shell is very thin, as can be expected for a holoplanktonic gastropod. Interestingly, already in the $19^{\text {th }}$ century it was assumed that Bellerophina minuta was holoplanktonic (see Böhm 1918 for a discussion).

The new genus Freboldia is placed in Bellerophinidae because it shares an inflated bilaterally symmetrical shell shape with deep umbilici with Bellerophina.

\section{Genus Freboldia Nützel \& Schneider gen. nov.}

Type species. - Freboldia fluitans sp. nov., by original designation herein. 
Etymology. - In honour of Hans Frebold (1899-1983), German palaeontologist, for his remarkable contributions to the palaeontology of the Arctic, including the Early Jurassic of Arctic Canada (see Teichert 1984 for details).

Diagnosis. - Small, inflated, planispiral, bilaterally symmetrical shell with deep umbilici; aperture higher than wide, kidney-shaped with concave inner and convex outer lip; mature shell smooth, with fine, regular growth lines only; growth lines straight, orthocline at periphery and tangential towards umbilici; shell thin, approximately 25-50 $\mu \mathrm{m}$ in thickness.

Remarks. - Freboldia gen. nov. resembles the Early Cretaceous probably holoplanktonic genus Bellerophina Destombes, 1983 (type species Bellerophina minuta) in its globular shape and bilateral symmetry and in having a very thin shell. However, Bellerophina has a distinct reticulate ornament of axial and spiral lirae whereas Freboldia is smooth. The Pliensbachian to Aalenian probably holoplanktonic genus Coelodiscus Brösamlen, 1909 is not bilaterally symmetrical but has either a slightly elevated or faintly depressed spire (see Teichert \& Nützel 2015). Moreover, Coelodiscus has a distinct, relatively dense spiral striation on the shell. The Early Jurassic genus Tatediscus resembles Coelodiscus in shape but differs from it and from Freboldia in having a conspicuous axial ornament.

Freshwater snails of the family Planorbidae, which ranges from the Jurassic to the Recent (Bandel 1991), hold forms that resemble Freboldia. However, they have shells of normal thickness, much thicker than in Freboldia, and a large protoconch with strong spiral cords (Riedel 1993). Moreover, Freboldia occurs in clearly marine sediment as indicated by the co-occurring mollusc fauna. Other Jurassic planispiral gastropods such as Discohelicidae differ from Freboldia in being widely phaneromphalous and disc-shaped instead of globular and involute.

Freboldia resembles the Palaeozoic to Early Triassic Bellerophontoidea in its bilaterally symmetrical shape, but this group is characterized by a median slit and selenizone and by having thicker shells.

The bilateral, planispiral, inflated shape of Freboldia also resembles the morphology of several Cenozoic to extant pteropods such as Sphaerocina Jung, 1971, Heliconoides d'Orbigny, 1835 and Currylimacina Janssen, 2003 (see e.g., Cahuzac \& Janssen 2010). However, these modern shells are distinctly more anisostrophically coiled (umbilici of unequal depth), and are sinistral especially in early whorls as is usual for coiled pteropod shells.
The possibility that Freboldia represents ammonitellas (early ontogenetic shells of ammonites) can be ruled out because internal moulds as well as thin sections revealed that septa are absent. Moreover, Mesozoic ammonitellas are much smaller than the present shells. De Baets et al. (2015, fig. 5.5) found that Jurassic ammonitellas are generally smaller than $1.5 \mathrm{~mm}$.

\section{Freboldia fluitans Nützel \& Schneider sp. nov.} Figures 3-8

Holotype. - CMN NUIF 422 (Fig. 4).

Other material. - Eight illustrated paratypes, CMN NUIF 1234-1241 (Figs 3, 5-7); a thin section yielding several specimens, CMN NUIF 1242 (Fig. 8); and numerous additional specimens, CMN NUIF 1243.

Type stratum. - Remus Member, Heiberg Formation, Early Jurassic, late Pliensbachian, Stokesi subzone.

Type locality. - River section northeast of Mount Bridgman (N 79 54.209, W 82 29.944$)$, on the eastern side of the Sawtooth Range on Fosheim Peninsula, Ellesmere Island, Nunavut Province, Arctic Canada.

Etymology. - From the Latin verb fluitare, meaning "drifting, floating", referring to the supposed planktonic style of living.

Description. - Shell small, with maximum diameter of $8 \mathrm{~mm}$ and maximum height of $6.3 \mathrm{~mm}$; inflated, globular, planispiral, bilaterally symmetric, with deep umbilici. Aperture higher than wide in lateral view, kidney-shaped, with concave inner and convex outer lip. Mature shell smooth, with growth-lines only; growth lines straight, orthocline at periphery and tangential towards umbilici. Early ontogenetic shell with faint spiral striation and minute tubercles. Shell thin, approximately $25-40 \mu \mathrm{m}$ in thickness.

Remarks. - Due to its bilaterally symmetrical shell, including umbilici of about the same depth and the overgrowth of the early whorls, it is unclear whether Freboldia fluitans has a dextral or sinistral mode of coiling. The smallest studied specimens (Fig. 7) have a diameter of about $1 \mathrm{~mm}$. Their earliest visible whorl portions indicate no sign of sinistral coiling. Therefore, it is unlikely that Freboldia is

Figure 5. Freboldia fluitans gen. nov. sp. nov., SEM micrographs. $\bullet$ A-D - paratype 3, CMN NUIF 1236; D showing thin shell, partly peeled off. • E, F - paratype 4, CMN NUIF 1237, juvenile whorls showing faint spiral ornament. 

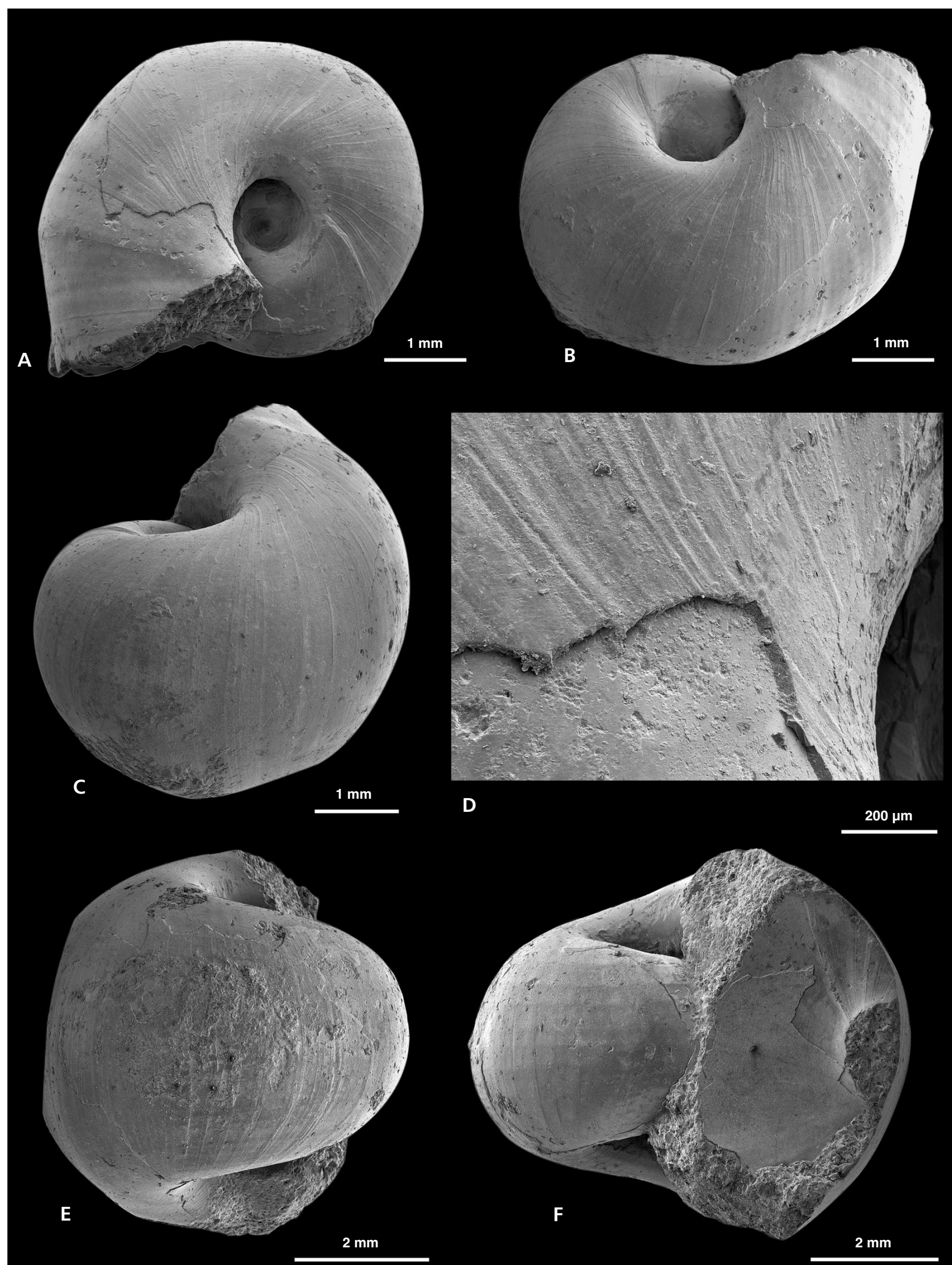
heterostrophic. However, the earliest portions of the whorls are covered by cement or matrix.

Since both the protoconch and the teleoconch are largely smooth, the transition from protoconch to teleoconch is indistinct, as is common in smooth-shelled fossil gastropods (see Nützel 2014). Whorls at a small shell size of distinctly less than $1 \mathrm{~mm}$ show a very fine micropunctation (Figs 6D-F, 7), which we could not detect in larger growth stages. We assume that this points to a larval shell of the planktotrophic type with fine micro-ornamentation. However, we were unable to document the termination of this possible larval shell and hence its exact size cannot be determined. To our knowledge, planispiral smooth larval shells with micro-punctation have not been reported from other holoplanktonic gastropods.

\section{Discussion}

The very thin shell, small size, bilaterally symmetrical shape and mass occurrence suggest a holoplanktonic lifestyle for Freboldia fluitans gen. et sp. nov. None of these arguments alone is unequivocal but overall, it is very likely that this gastropod had a planktonic lifestyle. The thin shell of $25-40 \mu \mathrm{m}$, in particular, represents important evidence for this hypothesis. Recent heteropods and pteropods have thin shells, which is undoubtedly an adaptation to the holoplanktonic lifestyle (weight reduction). Batten \& Dumont (1976) investigated the holoplanktonic heteropods Oxygyrus keraudreni (Lesueur, 1817), Protatlanta souleyeti (Smith, 1888) and Atlanta inclinata with regard to shell structure and reported shell thicknesses of less than $50 \mu \mathrm{m}$ for these species. Lalli \& Gilmer (1989) summarized that in shelled pteropods the shell thickness ranges from 6 to $100 \mu \mathrm{m}$, being "unusually thin". The same authors reported a shell thickness ranging from 4 to $40 \mu \mathrm{m}$ for atlantids (heteropods). Zhang et al. (2011) reported a shell thickness of 10 to $30 \mu \mathrm{m}$ for the recent pteropod Cavolinia uncinata. Other recent holoplanktonic snails have reduced their shell completely or use cartilageous instead of mineralic material.

The maximum shell size of less than $10 \mathrm{~mm}$ could also argue for a holoplanktonic lifestyle. Living atlantids and Pterotracheidae (the latter have only larval shells) as well as shelled pteropods usually have a shell diameter of less than $10 \mathrm{~mm}$ (Lalli \& Gilmer 1989). As an exception, Carinariidae may have shells of more than $100 \mathrm{~mm}$ length. The Early Cretaceous (Barremian to Aptian) Brunonia annulata (Yokoyama, 1890), which is the type species of Brunonia, has been placed in the planktonic heteropod family Carinariidae by Dieni (1990), who based his assumption mainly on the wide palaeogeographic distribution of this species. The limpet-shaped shell of Brunonia annulata is rather large, with distinct concentric annulations. Specimens from Japan reach $30 \mathrm{~mm}$ in diameter and specimens from Italy grew even as large as $6 \mathrm{~cm}$. The rather capuliform shells of Recent Carinaria may reach a length of $140 \mathrm{~mm}$ (A.W. Janssen written communication including illustration), and thus this rather large size does not argue against a planktonic mode of life. However, additional evidence such as information about shell thickness would be desirable to corroborate a pelagic mode of life for Brunonia.

The almost bilaterally symmetrical, coiled shell of Freboldia could also point to a planktonic lifestyle. As discussed above, this morphology also occurs in several modern pteropods. Bilateral symmetry is also present in uncoiled pteropods and in Cavolinia. Richter (1973) interpreted the bilateral symmetry of pelagic gastropods as an adaptation to an actively swimming lifestyle.

To our knowledge, a holoplanktonic mode of life has not been reported for Palaeozoic and Triassic gastropods. Certain exclusively Palaeozoic groups such as the straight-shelled Tentaculita have been assigned to pteropods but this attribution is generally not accepted any longer, although some of these forms had probably a planktonic life-style (e.g., Berkyová et al. 2007).

It is remarkable that there are no pre-Jurassic reports of pelagic gastropods. Putative holoplanktonic gastropods make their first appearance in the Early Jurassic, where the following seven genera are reported from Europe, South America and now the Canadian Arctic: Coelodiscus Brösamlen, 1909, Costasphaera Gründel \& Nützel, 2015 (in Nützel \& Gründel 2015), Freboldia gen. nov., Globorilusopsis Maubeuge, 1994, Pterotrachea Forsskål in Niebuhr, 1775 sensu Bandel \& Hemleben (1987), Simoniceras Maubeuge, 1998, Tatediscus Gründel, 2001 (Table 1).

In all of these genera, evidence for a pelagic lifestyle is circumstantial, similar to that discussed for Freboldia. Coelodiscus and Tatediscus are closely related to each other and form the family Coelodiscidae Gründel, 2013 (in Schulbert \& Nützel), which ranges from the Early Pliensbachian to the Early Aalenian (Schulbert \& Nützel 2013, Teichert \& Nützel 2015). They occur in oxygen-controlled environments in Central Europe and England (for

Figure 6. Freboldia fluitans gen. nov. sp. nov., SEM micrographs of early juvenile whorls. • A-C - paratype 5, CMN NUIF 1238; the pitted sculpture is not a shell ornament but represents impressions of a spherulithic A-cement that grew on the inner side of the of the peeled off shell. $\bullet$ D-F - paratype 6 , CMN NUIF 1239; small specimen, early juvenile or larval whorl with punctate micro-ornamentation. 

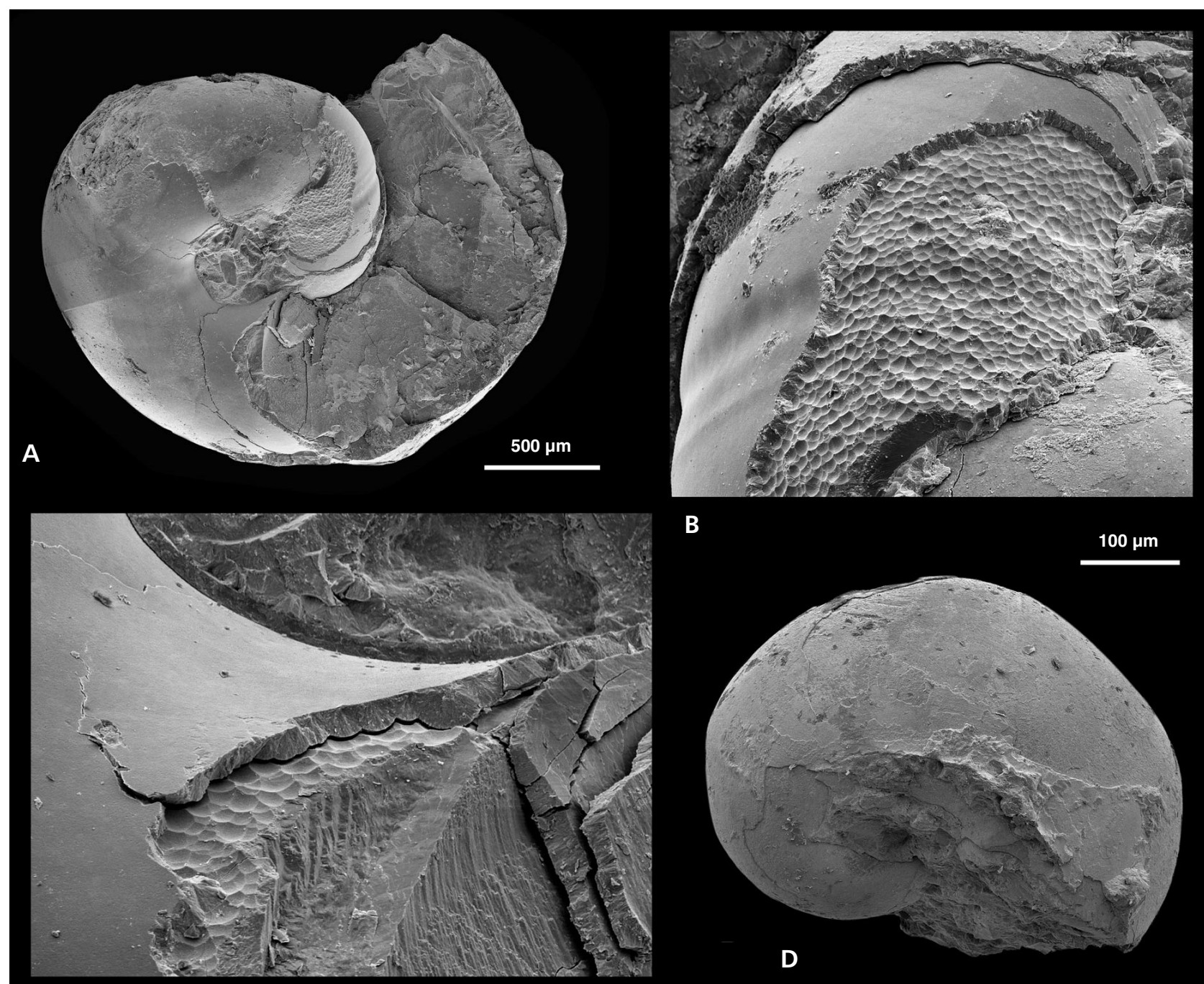

C

$100 \mu \mathrm{m}$

$500 \mu \mathrm{m}$
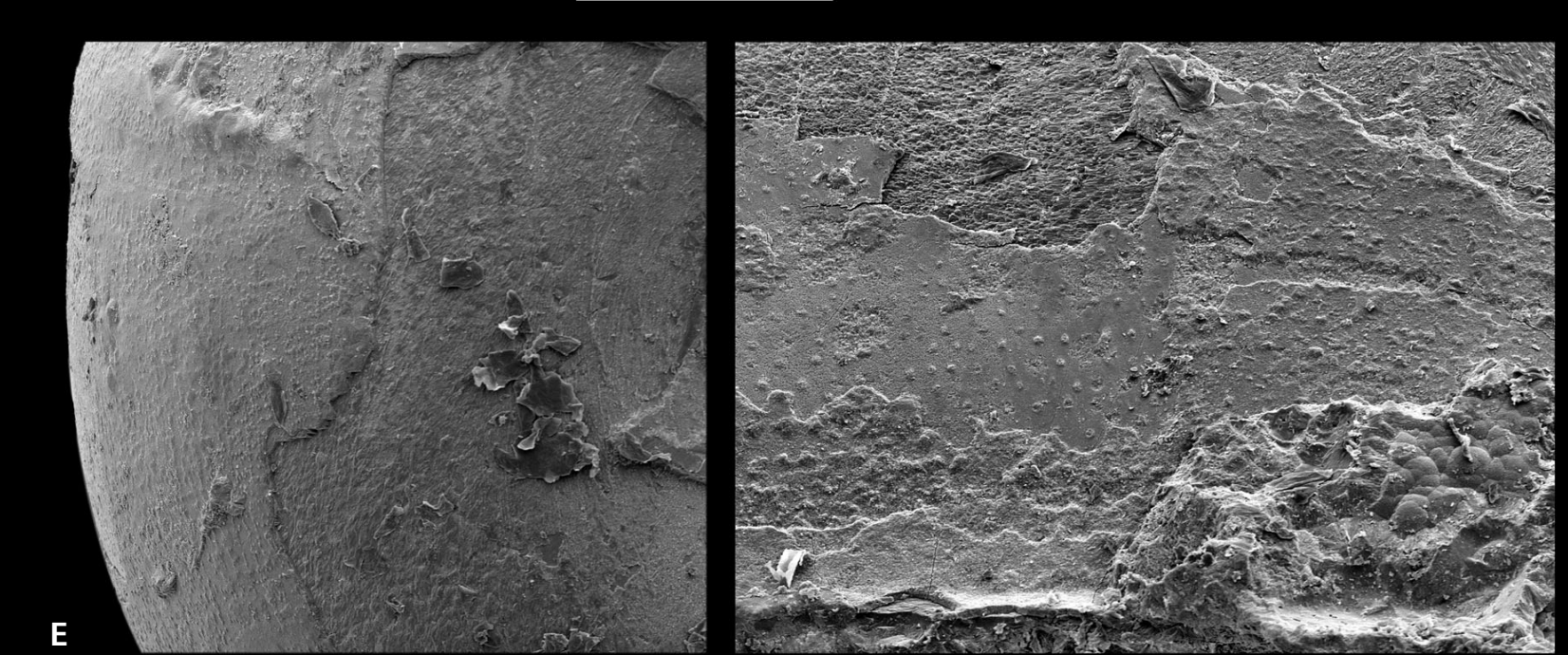

$100 \mu \mathrm{m}$ 


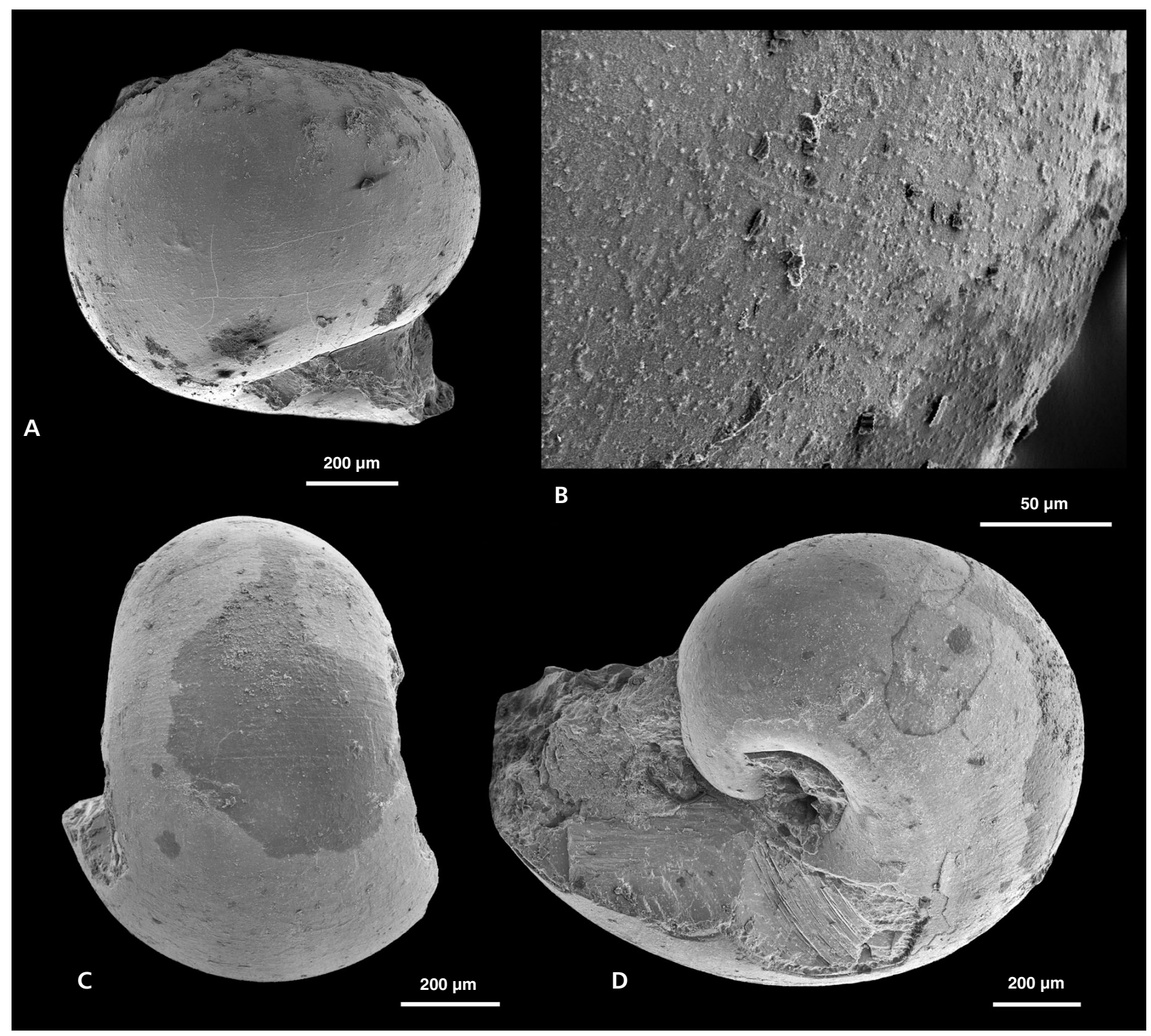

Figure 7. Freboldia fluitans gen. nov. sp. nov., SEM micrographs. $\bullet$ A, B - small specimen, probably larval shell with punctate micro-ornamentation. Paratype 7, CMN NUIF 1240. C, D - CMN NUIF 1241, small specimen; earliest portions of whorls show no indication of heterostrophy.

a discussion see Bandel \& Knitter 1983, 1986; Bandel \& Hemleben 1987; Teichert \& Nützel 2015) and have also been reported from Argentina (Gründel 2001).

Globorilusopsis and Simoniceras comprise several small species from the late Early Jurassic of Luxembourg, which are uncoiled to a variable degree. Maubeuge (1998) discussed a possible relationship with modern thecosomate pteropods but classified both Jurassic genera as small conoidal shells of uncertain affinity. There can be little doubt that these shells represent gastropods, based on their helicoidally coiled initial whorls. Based on their small size and general morphology, a pelagic lifestyle seems plausible. However, further study of shell thickness and protoconch morphology, in particular, is required.
Costasphaera, recently described by Nützel \& Gründel (2015), is a tiny, helicoidally coiled gastropod with strong ribbing pattern that was repeatedly reported from the Pliensbachian of southern Germany and England. The possibility that these shells represent larval shells of an unknown caenogastropod cannot be ruled out entirely, but so far they have never been found attached to adult shells although they occur in faunas with abundant benthic gastropods.

Pterotrachea is a living pelagic gastropod with a relatively large body that lacks an adult shell. However, it has a larval shell that is almost planispiral, either smooth or axially costate (Richter 1968). These larval shells are small and, according to published images, range from 0.4 to 

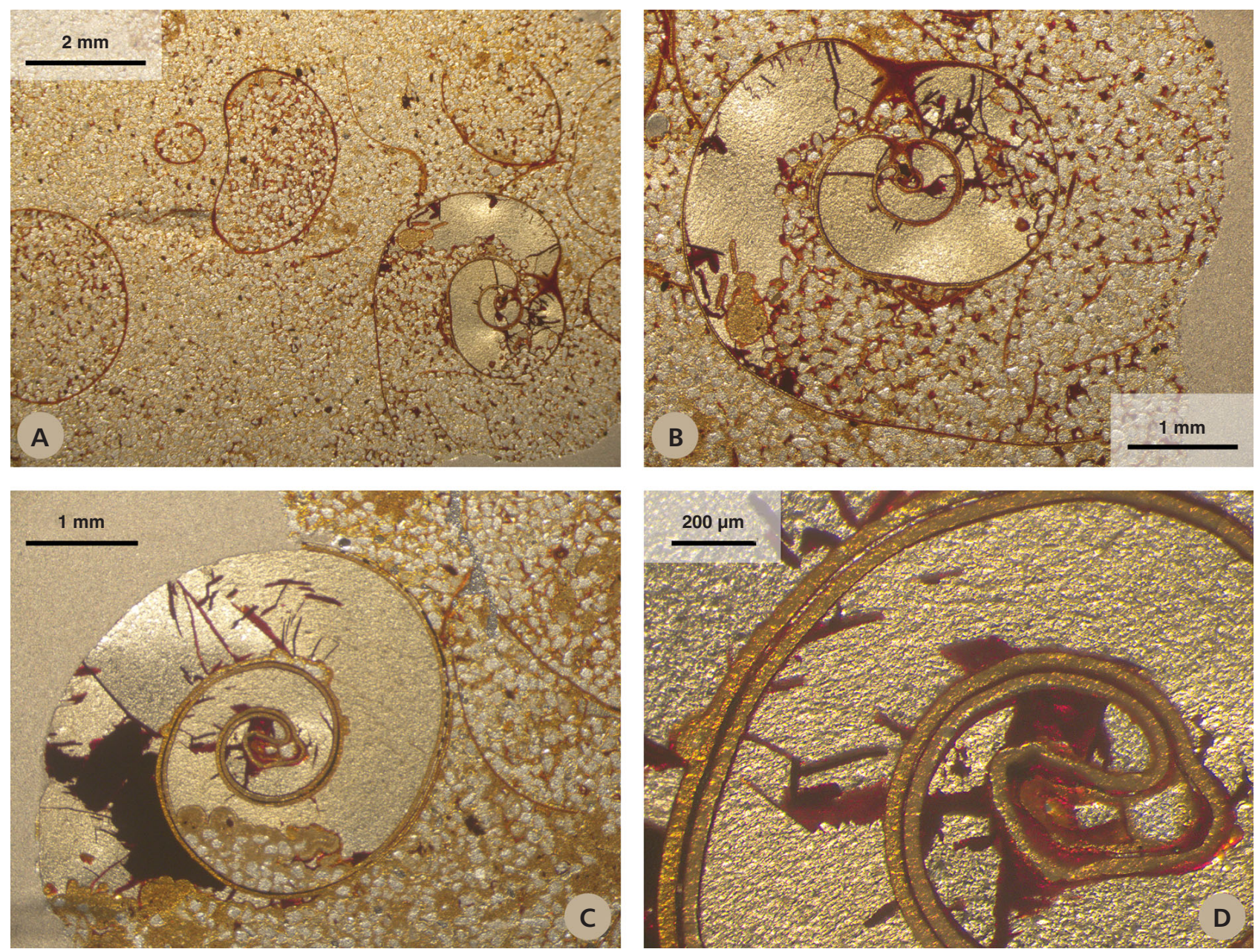

Figure 8. Thin section with Freboldia fluitans gen. nov. sp. nov., SEM micrographs. CMN NUIF 1242 (7634-41), scale bars A: 2 mm, B, C: 1 mm, D: $0.2 \mathrm{~mm}$

$0.7 \mathrm{~mm}$ in diameter (Richter 1968, Janssen in Tree of Life Web Project, accessed October 2015). Bandel \& Hemleben (1987) assigned the Toarcian "Ammonites" ceratophagus (alias Pterotrachea liassica) from Germany to the Recent heteropod genus Pterotrachea. We agree with the hypothesis that "Ammonites" ceratophagus is a pelagic gastropod, and a relationship with heteropods seems possible. However, Bandel \& Hemleben (1987) reported that the shell of this species has a diameter of up to $3.5 \mathrm{~mm}$; thus, it clearly does not represent a larval but an adult shell (see Nützel 2014). Therefore, a placement of these Jurassic shells in the Recent genus Pterotrachea is not justified, although the morphology of the Jurassic "Ammonites" ceratophagus and certain larval shells present in modern Pterotrachea is indeed similar.

As outlined above, the morphology of the new genus Freboldia is distinct from that of all other Jurassic putative pelagic gastropods and more similar to the Cretaceous Bellerophina. Jurassic pelagic gastropods also differ considerably from modern ones in shell morphology. Similar- ities in some forms are probably rather the result of convergence according to a similar lifestyle. At present, we do not think that Jurassic pelagic gastropods are direct ancestors of the modern ones. We speculate that the fossil groups became extinct and that modern pelagic gastropods evolved much later. These assumptions need corroboration by new fossil finds. However, as outlined by Janssen \& Peijnenburg (2013), the fossil record of holoplanktonic gastropods is hampered by their very thin aragonitic shells. In the discussed Jurassic forms, concretionary preservation plays a pivotal role because concretions are formed fast during early diagenesis and prevent compaction of the fragile shells.

This is also the case for Freboldia. Its shells were found accumulated in a single horizon within siltstone concretions that, apart from planktonic and nektonic elements, also preserve an autochthonous benthic fauna of various bivalves, scaphopods, small benthic gastropods and decapod crustaceans. These organisms testify a well-oxygenised sea bottom and upper sediment layer at moderately shallow 
Table 1. Jurassic gastropod genera with a putative holoplanktonic life style, their stratigraphic range and geographic distribution. The higher systematic placements of these genera are largely unknown although some have been attributed to heteropods (Caenogastropoda) or pteropods (Heterobranchia). *The placement of Early Jurassic shells in the modern genus Pterotrachea is doubtful (see discussion).

\begin{tabular}{lll}
\hline Genus & Stratigraphic range & Geographic distribution \\
\hline Coelodiscus & Pliensbachian-Aalenian & $\begin{array}{l}\text { Germany, England, } \\
\text { France, Switzerland }\end{array}$ \\
Costasphaera & Sinemurian-Pliensbachian & Germany, England \\
Freboldia & Pliensbachian & Arctic Canada \\
Globorilusopsis & Toarcian & Luxembourg \\
Pterotrachea* $^{*}$ & Toarcian-Recent & Germany \\
Simoniceras & Toarcian & Luxembourg \\
Tatediscus & Pliensbachian & England, Germany, \\
& & Argentina \\
\hline
\end{tabular}

depths (several tens of metres). Most bivalves are preserved with attached valves, indicating little or no transport. Consequently, the accumulation of fossils may be related to winnowing by bottom water currents or to a phase of rather low sediment deposition. Certainly, early lithification of the concretions has promoted the preservation of undistorted shells in all the rather small molluscs recorded.

In summary, there are five known groups of Early Jurassic pelagic gastropods representing seven genera. Some of these gastropods are abundant and widespread. This earliest radiation of the pelagic lifestyle in Gastropoda is particularly remarkable, because pre-Jurassic pelagic gastropods are unknown.

During and after the end-Triassic biotic crisis, anoxic or dysoxic bottom waters were wide-spread, likely related to changing oceanographic patterns due to the breakup of Pangaea and the opening of the Atlantic Ocean (Hallam 1981, Hallam \& Wignall 1997, van de Schootbrugge et al. 2013). Carbon cycle anomalies and recurrent anoxia persisted throughout much of the Hettangian (Bartolini et al. 2012), and further anoxic and dysoxic episodes are reported from the Sinemurian and Pliensbachian (van de Schootbrugge et al. 2013). Finally, the Pliensbachian-Toarcian Anoxic Event is well known as the most likely cause of the end-Pliensbachian extinction event. To sum up, oxygen deficiency was obviously a widespread phenomenon throughout much of the Early Jurassic.

Different scenarios have been proposed to explain this series of anoxia. However, increased input of organic matter from the continents has been generally suggested as a main driver. Bailey et al. (2003) suggested that global warming boosted continental weathering, freshwater runoff and the hydrologic cycle in general, resulting in a higher content of organic matter in the sea during anoxia. Van de Schootbrugge et al. (2013) also stated, "long-term ocean anoxia during the Early Jurassic can be attributed to greenhouse warming and increased nutrient delivery to the oceans" and hypothesized that this is "triggered by flood basalt volcanism".

The coincidence of repeated or long lasting anoxic or dysoxic conditions on the seafloor and the emergence of several pelagic gastropod groups within the Early Jurassic suggest that these phenomena might be causally linked. As hypothesized by Teichert \& Nützel (2015) for the pelagic Early Jurassic gastropod Coelodiscus, the poor benthic living conditions during anoxia could have triggered the evolution of a planktonic life style in several gastropod lineages. As most marine gastropods undergo a planktonic larval stage, the prolongation of this condition into a holoplanktonic adult mode of life seems to be a relatively simple step. Mainly, it involves the partial or complete reduction of the adult shell, as can be seen in many modern representatives. Obviously, maintaining functional digestive and reproductive systems requires more space than is provided in many of these relic shells and large parts of the body are thus often unprotected in modern holoplanktonic gastropods. Several representatives also have completely reduced their shells. A similar development within several of the Early Jurassic holoplanktonic clades could explain their disappearance from the successive Mesozoic fossil record.

\section{Acknowledgements}

Fieldwork in Arctic Canada would be impossible without support. In place of the numerous people involved, we express our sincere thanks to: the staff of the Polar Continental Shelf Program (PCSP, Ottawa and Resolute, Canada) and the Nunavut Research Institute (NRI, Iqaluit, Canada); Sylvie LeBlanc (Department of Culture and Heritage, Igloolik, Canada); Margaret Currie and Kieran Shepard (Museum of Nature, Ottawa, Canada); and our brilliant field assistants in summer 2013, Tim Burton (Sheffield, UK) and David Dockman (University of Alberta, Toronto, Canada). Magdalena Biszczuk (CASP, Cambridge, UK) has produced the maps. We thank Steffen Kiel (Stockholm) and Andrzej Kaim (Warszawa) for their constructive reviews. We also thank Arie W. Janssen who provided helpful information and discussions. We thank Martine Focke (München) for technical assistance. AN acknowledges financial support from the Deutsche Forschungsgemeinschaft (Project NU 96/11-1).

\section{References}

Bailey, T.R., Rosenthal, Y., McArthur, J.M., van DE Schootbrugge, B. \& Thirlwall, M.F. 2003. Paleoceanographic changes of the Late Pliensbachian-Early Toarcian interval: a possible link to the genesis of an Oceanic Anoxic Event. Earth and Planetary Science Letters 212, 307-320. DOI 10.1016/S0012-821X(03)00278-4 
Bandel, K. \& Hemleben, C. 1987. Jurassic heteropods and their modern counterparts (planktonic Gastropoda, Mollusca). Neues Jahrbuch für Geologie und Paläontologie, Abhandlungen 174, 1-22.

BANDEL, K. \& KNITTER, H. 1983. Litho- und biofazielle Untersuchung eines Posidonienschieferprofils in Oberfranken. Geologische Blätter für Nordostbayern 32, 95-129.

BANDEL, K. \& KNITTER, H. 1986. On the origin and diagenesis of the bituminous Posidonia Shale (Toarcian) of Southern Germany. Mitteilungen aus dem Geologisch-Paläontologischen Institut der Universität Hamburg 60, 151-177.

Bartolini, A., Guex, J., Spangenberg, J.E., Schoene, B., TAylor, D.G., Schaltegger, U. \& Atudorei, V. 2012. Disentangling the Hettangian carbon isotope record: Implications for the aftermath of the end-Triassic mass extinction. Geochemistry, Geophysics, Geosystems 13, Q01007. DOI 10.1029/2011GC003807

Batten, R.L. \& Dumont, M.P. 1976. Shell ultrastructure of the Atlantidae (Heteropoda, Mesogastropoda) Oxygyrus and Protatlanta, with comments on Atlanta inclinata. Bulletin of the American Museum of Natural History 157, 267-310.

BerkyovÁ, S., FrÝdA, J. \& LuKEš, P. 2007. Unsuccessful predation on Middle Paleozoic plankton: Shell injury and anomalies in Devonian dacryoconarid tentaculites. Acta Palaeontologica Polonica 52, 407-412.

BöHM, J. 1918. Literarische Bemerkung zur Gattung Bellerophina d'Orb. Zeitschrift der Deutschen Geologischen Gesellschaft 70, 170-173.

BrösAmLen, R. 1909 Beitrag zur Kenntnis der Gastropoden des Schwäbischen Jura. Palaeontographica 56, 177-322.

Cahuzac, B. \& Janssen, A.W. 2010. Eocene to Miocene holoplanktonic Mollusca (Gastropoda) of the Aquitaine Basin, southwest France. Scripta Geologica 141, 1-193.

Chen, C. 1964. Pteropod ooze from Bermuda Pedestal. Science 144, 60-62. DOI 10.1126/science.144.3614.60

De Baets, K., Landmann, N.H. \& Tanabe, K. 2015. Ammonoid embryonic development, 113-205. In KLuG, C., KoRn, D., DE Baets, K., Kruta, I. \& MAPEs, R.H. (eds) Ammonoid paleobiology: from anatomy to ecology. Springer, Berlin.

Destombes, P. 1984. Récherches sur la mesofaune de l'Albien Inférieur de Bully-Saint- Martin 1'Hortier (Pays de Bray). Bulletin trimestriel de la Sociéte Géologique de Normandie et des Amis du Muséum du Havre 70, 41-58.

DienI, I. 1990. Brunonia annulata (Yokoyama, 1890) (Carinariidae, Mesogastropoda) nel Cretaceo inferiore della Sardegna. Bollettino della Società Paleontologica Italiana 29, $43-51$.

Dommergues, J.-L., Meister, C. \& Mouterde, R. 1997. Pliensbachien, 15-23, 114-119. In CARIOU, E. \& HANTZPERGUE, P. (eds) Biostratigraphie du Jurassique ouesteuropéen et méditerranéen: zonations parallèles et distribution des invertébrés et microfossiles. Bulletin du Centre Recherche, Elf Exploration et Production, Pau, Mémoire 17.

EmBry, A.F. 1983. Stratigraphic subdivision of the Heiberg Formation, eastern and central Sverdrup Basin, Arctic Islands. Geological Survey of Canada, Paper 83-1B, 205-213.

Embry, A.F. 1984. The Wilkie Point Group (Lower-Upper Jurassic) Sverdrup Basin, Arctic Islands. Geological Survey of Canada, Paper 84-1B, 299-308.
Embry, A.F. \& Beauchamp, B. 2008. Sverdrup Basin, 451-471. In Miall, A.D. (ed.) Sedimentary Basins of the World. University of Toronto, Toronto.

DOI 10.1016/S1874-5997(08)00013-0

EMBRY, A.F. \& JoHANNESSEN, E.P. 1992. T-R sequence stratigraphy, facies analysis and reservoir distribution in the uppermost Triassic - Lower Jurassic succession, western Sverdrup Basin, Arctic Canada, 121-146. In Vorren, T.O., Bergsager, E., Dahl-Stamnes, O.A., Holter, E., Johansen, B., Lie, E. \& Lund, T.B. (eds) Arctic geology and petroleum potential. Norwegian Petroleum Society (NPF), Special Publication 2.

Embry, A.F. \& SunEBy, L.B. 1995. The Triassic-Jurassic boundary in the Sverdrup Basin, Arctic Canada, 857-868. In EMBRY, A.F., Beauchamp, B. \& Glass, D.J. (eds) Pangea: global environments and resources: Proceedings of the Pangea Conference. Canadian Society of Petroleum Geologists, Memoir 17.

Frebold, H. 1975. The Jurassic faunas of the Canadian Arctic. Lower Jurassic ammonites, biostratigraphy and correlations. Geological Survey of Canada, Bulletin 243, 1-24. DOI 10.4095/103979

GRÜNDEL, J. 2001. Gastropoden aus dem Jura der südamerikanischen Anden. Freiberger Forschungshefte $C$ 492, 43-84.

Hallam, A. 1981. The end-Triassic bivalve extinction event. Palaeogeography, Palaeoclimatology, Palaeoecology 35, 1-44. DOI 10.1016/0031-0182(81)90092-4

Hallam, A. \& Wignall, P.B. 1997. Mass extinctions and their aftermath. 320 pp. Oxford University Press, Oxford.

Harrison, J.C., St-Onge, M.R., Petrov, O.V., Strelnikov, S.I., Lopatin, B.G., Wilson, F.H., Tella, S., Paul, D., Lynds, T., Shokalsky, S.P., Hults, C.K., Bergman, S., Jepsen, H.F. \& SolLi, A. 2011. Geological map of the Arctic. Geological Survey of Canada, "A" Series Map 2159A.

JANSSEN, A.W. 2003. Notes on the systematics, morphology and biostratigraphy of fossil holoplanktonic Mollusca, 13. Considerations on a subdivision of Thecosomata, with the emphasis on genus group classification of Limacinidae. Cainozoic Research 2, 163-170.

Janssen, A.W. \& Peijnenburg, K.T.C.A. 2013. Holoplanktonic Mollusca: development in the Mediterranean Basin during the last $30 \mathrm{Ma}$ and their future, 341-362. In GofFredo, S. \& Dubinsky, Z. (eds) The Mediterranean Sea. Its history and present challenges. Springe, Dordrecht.

Jung, P. 1971. Fossil mollusks from Carriacou, West Indies. Bulletins of American Paleontology 61(269), 147-262.

LALLI, C.M. \& GILMER, R.W. 1989. Pelagic snails - the biology of holoplanktonic gastropod molluscs. 258 pp. Stanford University Press, Stanford.

Lesueur, C.A. 1817. Mémoire sur deux nouveaux genres de mollusques, Atlante et Atlas. Journal de Physique 85, 390-393.

Maubeuge, P.L. 1994. Globorilusopsis, nouveau Genre: Survivance de Calyptotomatidae au Jurassique. Bulletin des Académie et Société Lorraines des Sciences 33, 141-148.

Maubeuge, P.L. 1998. Etude sur les genres Globorilusopsis Maubeuge, 1994 et Simoniceras n. gen. du Lias Supérior du Grand-Duché de Luxembourg (Calyptoptomatida). Travaux Scientifiques du Musée National d'Histoire Naturelle de Luxembourg 29, 1-89. 
Niebuhr, C. (ed.) 1775. Descriptiones animalium avium, amphibiorum, piscium, insectorum, vermium quae in itinere orientali observavit Petrus Forskål, prof. Haun., post mortem auctoris edidit Carsten Niebuhr. xxxiv +164 pp. Möller, Hauniae.

NÜTZEL, A. \& GRÜNDEL, J. 2015. Early Jurassic (Pliensbachian) gastropods from Franconia, South Germany. Palaeontographica A 305, 1-87. DOI 10.1127/pala/305/2015/1

OrbignY, A. D' 1834-1847. Voyage dans l'Amérique méridionale (le Brésil, la république orientale de l'Uruguay, la république Argentine, la Patagonie, la république du Chili, la république de Bolivia, la république du Pérou), exécuté pendant les années 1826, 1827, 1828, 1829, 1830, 1831, 1832 et 1833. xliii +758 pp. Bertrand \& Levrault, Paris \& Strasbourg.

Poulton, T.P. 1993. Jurassic stratigraphy and fossil occurrences - Melville, Prince Patrick, and Borden Islands. Geological Survey of Canada, Bulletin 450, 161-193.

Richter, G. 1968. Heteropoden und Heteropodenlarven im Oberflächenplankton des Golfes von Neapel. Pubblicazioni della Stazione zoologica di Napoli 36, 347-400.

Richter, G. 1973. Zur Stammesgeschichte pelagischer Gastropoden. Natur und Museum 103, 265-275.

RiedEL, F. 1993. Early ontogenetic Shell Formation in some freshwater gastropods and taxonomic implications of the protoconch. Limnologica 23, 349-368.

Schulbert, C. \& NÜtZel, A. 2013. Gastropods from the Early/Middle Jurassic transition of Franconia (Southern Germany). Bulletin of Geosciences 88, 723-778. DOI 10.3140/bull.geosci.1418

Simms, M.J., Chidlaw, N., Morton, N. \& Page, K.N. 2004. British Lower Jurassic Stratigraphy. Geological Conservation Review Series 30, 1-458.

SMith, E.A. 1888. Report on the Heteropoda collected by HMS Challenger during the years 1873-1876. Reports of the scientific results of the voyage of H.M.S. "Challenger", Zoology 23 (part 72), 1-51 prepared by Dr. David C. Bossard, Dartmouth College, Hanover New Hampshire.

SOWERBY, J. 1812-1822. The mineral conchology of Great Britain; or coloured figures and descriptions of those remains of testaceous animals or shells, which have been preserved at various times and depths in the Earth. 803 pp. Benjamin Meredith, London.

Teichert, C. 1984. Hans Frebold, 31 July 1899 - 2 June 1983. Bulletin of the Geological Society of Denmark 32, 181-185.

Teichert, S. \& NütZEL, A. 2015. Early Jurassic anoxia triggered the evolution of the oldest holoplanktonic gastropod Coelodiscus minutus by means of heterochrony. Acta Palaeontologica Polonica 60, 269-276.

Thorsteinsson, R. 1972. Geology, Canon Fiord, District of Franklin. Geological Survey of Canada, "A" Series Map 1308 A.

Tracey, S., Todd, J.A. \& ERwin, D.H. 1993. Mollusca: Gastropoda, 131-167. In BENTON, M.J. (ed.) The fossil record. Chapman and Hall, London.

van Hinsbergen, D.J.J., de Groot, L.V., van Schaik, S.J., Spakman, W., Bijl, P.K., Sluijs, A., Langereis, C.G. \& BRINKHUIS, H. 2015. A paleolatitude calculator for paleoclimate studies. PLoS ONE 10(6), e0126946, 1-21. DOI 10.1371/journal.pone.0126946

van de Schootbrugge, B., Bachan, A., Suan, G. \& Richoz, S. 2013. Microbes, mud and methane: cause and consequence of recurrent Early Jurassic anoxia following the end-Triassic mass extinction. Palaeontology 56, 685-709. DOI 10.1111/pala.12034

Yокоунма, M. 1890. Versteinerungen aus der japanischen Kreide. Palaeontographica 36, 159-202.

Zhang, T., Ma, Y., Chen, K., Kunz, M., Tamura, N, Qiang, M., XU, J. \& QIN, L. 2011. Structure and mechanical properties of a pteropod shell consisting of interlocked helical aragonite nanofibers. Angewandte Chemie, International Edition 50, 10361-10365. 